\title{
Vertical activity distribution of dissimilatory nitrate reduction in coastal marine sediments
}

\author{
A. Behrendt ${ }^{1}$, D. de Beer ${ }^{1}$, and P. Stief ${ }^{1,2}$ \\ ${ }^{1}$ Max Planck Institute for Marine Microbiology, Microsensor Group, Bremen, Germany \\ ${ }^{2}$ University of Southern Denmark, Department of Biology, NordCEE, Odense, Denmark
}

Correspondence to: A. Behrendt (abehrend@mpi-bremen.de)

Received: 25 April 2013 - Published in Biogeosciences Discuss.: 14 May 2013

Revised: 19 September 2013 - Accepted: 15 October 2013 - Published: 21 November 2013

\begin{abstract}
The relative importance of two dissimilatory nitrate reduction pathways, denitrification (DEN) and dissimilatory nitrate reduction to ammonium (DNRA), was investigated in intact sediment cores from five different coastal marine field sites (Dorum, Aarhus Bight, Mississippi Delta, Limfjord and Janssand). The vertical distribution of DEN activity was examined using the acetylene inhibition technique combined with $\mathrm{N}_{2} \mathrm{O}$ microsensor measurements, whereas $\mathrm{NH}_{4}^{+}$production via DNRA was measured with a recently developed gel probe-stable isotope technique. At all field sites, dissimilatory nitrate reduction was clearly dominated by DEN (59-131 \% of the total $\mathrm{NO}_{3}^{-}$reduced) rather than by DNRA, irrespective of the sedimentary inventories of electron donors such as organic carbon, sulfide, and iron. Highest ammonium production via DNRA, accounting for up to $8.9 \%$ of the total $\mathrm{NO}_{3}^{-}$reduced, was found at a site with very high concentrations of total sulfide and $\mathrm{NH}_{4}^{+}$within and below the layer in which $\mathrm{NO}_{3}^{-}$reduction occurred. Sediment from two field sites, one with low and one with high DNRA activity in the core incubations, was also used for slurry incubations. Now, in both sediments high DNRA activity was detected accounting for $37-77 \%$ of the total $\mathrm{NO}_{3}^{-}$reduced. These contradictory results might be explained by enhanced $\mathrm{NO}_{3}^{-}$availability for DNRA bacteria in the sediment slurries compared to the core-incubated sediments in which diffusion of $\mathrm{NO}_{3}^{-}$from the water column may only reach DEN bacteria, but not DNRA bacteria. The true partitioning of dissimilatory nitrate reduction between DNRA and DEN may thus lie in between the values found in whole core (underestimation of DNRA) and slurry incubations (overestimation of DNRA).
\end{abstract}

\section{Introduction}

The balance between retention and loss of fixed nitrogen, especially $\mathrm{NO}_{3}^{-}$, in coastal marine ecosystems is crucial as it defines the degree of eutrophication in these environments (Burgin and Hamilton, 2007; Herbert, 1999; King and Nedwell, 1985). Sediments play a key role in the biological turnover of fixed nitrogen in shallow aquatic environments by hosting microbially mediated processes such as nitrification, anaerobic ammonia oxidation (anammox), and denitrification (Thamdrup and Dalsgaard, 2008). Anammox and denitrification convert fixed nitrogen into dinitrogen that can leave the ecosystem and thus these two processes contribute to fixed nitrogen removal. The relative contribution of anammox to fixed nitrogen removal is, however, particularly low in very shallow coastal marine sediments (Dalsgaard et al., 2005; Thamdrup, 2012). A third anaerobic process involved in fixed nitrogen conversion is dissimilatory nitrate reduction to ammonium (DNRA). Ammonium produced via DNRA is recycled either within the sediment or in the water column into which it diffuses and hence DNRA may sustain coastal eutrophication. In the anoxic layer of marine sediments, denitrification (DEN) and DNRA directly compete for $\mathrm{NO}_{3}^{-}$as an electron acceptor and for organic carbon, sulfide, and others as electron donors. The outcome of this competition determines whether marine sediments act as source or sink of fixed nitrogen, which has impacts for the trophic status of the whole ecosystem.

While denitrification is a well studied pathway and known as an important sink for $\mathrm{NO}_{3}^{-}$in marine sediments (Herbert, 1999; Seitzinger, 1988), the environmental importance of DNRA is less well known. Lately, however, reports on 
high DNRA rates in various aquatic environments are accumulating. Estuaries (An and Gardner, 2002; Kelly-Gerreyn et al., 2001), aquaculture systems (Christensen et al., 2000; Gilbert et al., 1997; Nizzoli et al., 2006), a salt marsh (KoopJakobsen and Giblin, 2010), and freshwater sediment (Brunet and GarciaGil, 1996) have been identified as sites where DNRA plays a significant role in the nitrogen budget. Environmental conditions often regarded as controlling factors of the competition between DEN and DNRA include the carbon-to-nitrate ratio (e.g., Herbert, 1999; Kelso et al., 1999; Strohm et al., 2007; Tiedje et al., 1982; Yin et al., 2002), sulfide (e.g., An and Gardner, 2002; Brunet and GarciaGil, 1996), iron (Edwards et al., 2007; Lovley et al., 2004; Weber et al., 2006b), and temperature (Dong et al., 2011; Jørgensen, 1989; Ogilvie et al., 1997). Specifically, high relative contributions of DNRA to total dissimilatory nitrate reduction have been ascribed to high carbon-to-nitrate ratios, high sulfide and reduced iron concentrations, and high temperatures.

Studies on the identification of these possible controlling factors have mostly used slurry incubations of sediment (Bonin et al., 1998; Fernandes et al., 2012; Lansdown et al., 2012), whole sediment core incubations with a final destructive sampling of the upper sediment layers (Christensen et al., 2000; Dong et al., 2009; Dunn et al., 2012), or whole sediment core incubations in which only the in- and outflow of the water column were analysed (Gardner and McCarthy, 2009; Gardner et al., 2006; Smyth et al., 2013). The major limitation of these approaches is that the controlling factors are not studied directly in the intact nitratereducing sediment layer. In slurry incubations, all in situ gradients are destroyed and the conditions formerly established in the nitrate-reducing and the neighbouring sediment layers are blended. Furthermore, rates determined in slurries often overestimate the in situ rates (Christensen et al., 2000; Revsbech et al., 2006). Whole core incubations have the advantage that the biological and chemical stratification of the sediment stays intact during the incubation (but not necessarily during experimental sampling). The distinct investigation of the nitrate-reducing sediment layer, however, is not targeted by this method, neither in terms of nitrogen conversions, nor in terms of the controlling factors. We therefore investigated sediment cores with intact biological and chemical stratification during experimental incubation and sampling with respect to the vertical distribution of DEN and DNRA activities and the hypothesized controlling factors in the sediment. Coastal marine sediments were sampled at five field sites that differed in several environmental and sediment parameters and were analysed in the laboratory. DEN activity was measured with the acetylene blocking technique combined with $\mathrm{N}_{2} \mathrm{O}$ microsensor measurements, whereas DNRA activity was measured with a newly developed gel probe-stable isotope technique. In parallel sediment cores, the vertical distribution of possible controlling factors was analysed. For a methodical comparison, sediment from two contrasting field sites was investigated in both whole core and slurry incubations.

\section{Materials and methods}

\subsection{Sampling sites}

Intact sediment cores were collected at five coastal marine sites between September 2009 and July 2011. The sampling sites were Dorum, an intertidal flat north of Bremerhaven (Germany), Station M5 in Aarhus Bight (Denmark), the Mississippi Delta near Chauvin (USA), the Hjarbæk Fjord within the Limfjord (Denmark) and the low-water line of Janssand (near sulfidic seeps), a back barrier tidal flat of Spiekeroog Island (Wadden Sea, Germany).

These sites were chosen to cover a range of sediment characteristics that might influence the rates of dissimilatory nitrate reduction pathways (e.g., organic carbon and sulfide contents). Site characteristics and sampling details are given in Table 1.

At each site, 6-10 sediment cores were taken with acrylic core liners with an inner diameter of $9 \mathrm{~cm}$ and a length of $20 \mathrm{~cm}$. The final height of the sediment and the water column in the core liners were 15 and $5 \mathrm{~cm}$, respectively. Care was taken to avoid macrofauna burrows and shell debris during coring. The sediment cores were transported to the laboratory within $1-6 \mathrm{~h}$ and then immediately connected to the experimental setup as described below.

For additional sediment slurry experiments, surface sediment ( $0-2 \mathrm{~cm}$ depth) was sampled from Dorum and from two sites of Janssand (i.e., from the upper sand flat and from the low-water line near a sulfidic seep) in October 2012.

\subsection{Experimental setup and sampling design}

Six intact sediment cores were connected to an incubation set-up, in which the overlying seawater was aerated and continuously exchanged from a reservoir $(10 \mathrm{~L})$ to maintain stable conditions at the sediment surface. The water level was kept constant by drawing off excess overlying water with a peristaltic pump. Seawater was prepared from Red Sea Salt (Red Sea Fish Farm, Israel) at the salinity of the respective sampling site and a $\mathrm{pH}$ of 8.0-8.4. The seawater was amended with $\mathrm{NaNO}_{3}$ to a final concentration of $50 \mu \mathrm{mol} \mathrm{L}{ }^{-1} \mathrm{NO}_{3}^{-}$which was mostly higher than in situ (except for Mississippi Delta where it was lower; Table 1). The sediment cores were incubated at a constant temperature that was close to the in situ temperature at the time of sediment collection (Table 1). After starting the pumps, the overlying water of the cores reached a stable concentration of $50 \mu \mathrm{mol} \mathrm{L}^{-1} \mathrm{NO}_{3}^{-}$within 1 day, but a further incubation for 3-5 days was scheduled to allow steady-state conditions to develop inside the sediments. The $\mathrm{NO}_{3}^{-}$concentration of the overlying water was monitored each day and corrected if necessary. Additional cores for sediment analyses were 
Table 1. Location and characteristics of sampling sites.

\begin{tabular}{|c|c|c|c|c|c|c|}
\hline Sampling site & Coordinates & Ecosystem & Sediment texture & Temp. $\left({ }^{\circ} \mathrm{C}\right)$ & Salinity $(\% o)^{*}$ & $\mathrm{NO}_{3}^{-}(\mu \mathrm{mol} \mathrm{L}-1)^{*}$ \\
\hline Dorum & $\begin{array}{l}53^{\circ} 44^{\prime} 11.39^{\prime \prime} \mathrm{N} \\
8^{\circ} 30^{\prime} 27.22^{\prime \prime} \mathrm{E}\end{array}$ & Intertidal flat & Sandy & 16.3 & 31 & 12 \\
\hline Aarhus Bight & $\begin{array}{l}56^{\circ} 06^{\prime} 20^{\prime \prime} \mathrm{N} \\
10^{\circ} 27^{\prime} 47^{\prime \prime} \mathrm{E}\end{array}$ & Coastal bay & Muddy & 2.9 & 25 & 4 \\
\hline Mississippi Delta & $\begin{array}{l}29^{\circ} 13^{\prime} 33.00^{\prime \prime} \mathrm{N} \\
8^{\circ} 30^{\prime} 27.22^{\prime \prime} \mathrm{W}\end{array}$ & River delta & Muddy & 30.5 & 12 & 2 \\
\hline Limfjord & $\begin{array}{l}56^{\circ} 32^{\prime} 13.52^{\prime \prime} \mathrm{N} \\
9^{\circ} 22^{\prime} 12.23^{\prime \prime} \mathrm{E}\end{array}$ & Shallow fjord & Muddy & 16.6 & 2 & 124 \\
\hline Janssand & $\begin{array}{l}53^{\circ} 44^{\prime} 7.17^{\prime \prime} \mathrm{N} \\
7^{\circ} 41^{\prime} 48.90^{\prime \prime} \mathrm{E}\end{array}$ & Intertidal flat & Sandy-to-muddy & 15.5 & 35 & 2 \\
\hline
\end{tabular}

* Salinity and $\mathrm{NO}_{3}^{-}$concentration in the water column. Samples were taken between September 2009 and July 2011.

kept submersed in an aquarium under the same conditions as in the incubation set-up. After the pre-incubation period, the vertical distribution of DNRA and DEN activities and of physical-chemical parameters assumed to influence these two pathways were measured in whole sediment cores.

\subsection{Sediment slurry incubations}

In addition to the whole core incubations, slurry experiments were conducted with sediment from Dorum and Janssand (upper tidal flat vs. low-water line near a sulfidic seep). Approximately $1 \mathrm{~g}$ of homogenized sediment was transferred into $6 \mathrm{~mL}$ exetainers ( 7 for DEN and 7 for DNRA rate measurements) and mixed with $3 \mathrm{~mL}$ of anoxic $35 \%$ artificial seawater (Red Sea Salt, Red Sea Fish Farm, Israel). The water was amended with $50 \mu \mathrm{mol} \mathrm{L}^{-1}{ }^{15} \mathrm{NO}_{3}^{-}(99 \%$ ${ }^{15} \mathrm{~N}$ atom $\%$, Cambridge Isotope Laboratories, Andover, MA, USA). The exetainers were flushed for $3 \mathrm{~min}$ with $\mathrm{He}$ to create anoxic conditions and then continuously rotated in a dark incubator at room temperature. At each of 7 sampling time points, 2 exetainers were sacrificed, 1 for DEN and 1 for DNRA rate measurements. Biological activity in the DEN exetainers was terminated by adding $500 \mu \mathrm{L}$ of $50 \% \mathrm{ZnCl}_{2}$ and stored for later analysis of ${ }^{15} \mathrm{~N}_{2}$ and $\mathrm{N}_{2} \mathrm{O}$. DEN activity was measured in a headspace volume of $250 \mu \mathrm{L}$ to determine the isotope ratio of ${ }^{28} \mathrm{~N}_{2},{ }^{29} \mathrm{~N}_{2}$, and ${ }^{30} \mathrm{~N}_{2}$ by gas chromatography-isotopic ratio mass spectrometry (VG Optima, ISOTECH, Middlewich, UK) against air standards. $\mathrm{N}_{2} \mathrm{O}$ concentration was measured in a headspace volume of $250 \mu \mathrm{L}$ by gas chromatography (GC 7890 Agilent Technologies). The DNRA exetainers were amended with $1 \mathrm{~mL}$ of $3 \mathrm{M}$ $\mathrm{KCl}$ to aid desorption of $\mathrm{NH}_{4}^{+}$from the sediment particles. Liquid subsamples were quickly taken from the DNRA exetainers and transferred into fresh vials for subsequent analysis of $\mathrm{NO}_{3}^{-}, \mathrm{NH}_{4 \text { tot }}^{+}$, and ${ }^{15} \mathrm{NH}_{4}^{+}$. $\mathrm{NO}_{3}^{-}$was analysed in $25-\mu \mathrm{L}$ samples after chemical conversion to $\mathrm{NO}$ that was quantified by the chemoluminescence detector of an $\mathrm{NO}_{\mathrm{x}}$ analyser (CLD 66, EcoPhysics, Germany) (Braman and Hendrix, 1989). In the following, the $\mathrm{NO}_{\mathrm{x}}$ data are reported as
$\mathrm{NO}_{3}^{-}$concentrations, since $\mathrm{NO}_{2}^{-}$concentrations were generally very low. $\mathrm{NH}_{4}^{+}$was analysed with the salicylatehypochlorite method scaled down to $1 \mathrm{~mL}$ samples (Bower and Holm-Hansen, 1980). ${ }^{15} \mathrm{NH}_{4}^{+}$concentration (indicating DNRA activity) was determined after the hypobromite assay was applied. To this end, $250 \mu \mathrm{L}$ was transferred into a $3 \mathrm{~mL}$ exetainer and flushed twice with $\mathrm{He}$ for $60 \mathrm{~s}$ (with 1 min equilibration time in between). $12 \mathrm{M} \mathrm{NaOH}$ and hypobromite were injected to convert $\mathrm{NH}_{4}^{+}$to $\mathrm{N}_{2}$ (Warembourg, 1993). Samples were left for 3 days at $21^{\circ} \mathrm{C}$ in the dark to allow the reaction to $\mathrm{N}_{2}$ to proceed. In headspace samples of $250 \mu \mathrm{L}$, the isotope ratio of ${ }^{28} \mathrm{~N}_{2},{ }^{29} \mathrm{~N}_{2}$, and ${ }^{30} \mathrm{~N}_{2}$ was determined by gas chromatography-isotopic ratio mass spectrometry (VG Optima, ISOTECH, Middlewich, UK) against air standards. Calibration standards were prepared with MilliQ water adjusted to different ${ }^{15} \mathrm{NH}_{4}^{+}$concentrations $(0,5,10$, and $25 \mu \mathrm{mol} \mathrm{L}{ }^{-1} ;{ }^{15} \mathrm{NH}_{4} \mathrm{Cl} 98 \%{ }^{15} \mathrm{~N}$ atom $\%$, Cambridge Isotope Laboratories, Andover, MA, USA). Linear concentration changes over the time were used for rate calculations.

\subsection{Microsensor measurements}

Microsensors for $\mathrm{O}_{2}$ (Revsbech, 1989), $\mathrm{NO}_{3}^{-}$(Larsen et al., 1997), $\mathrm{H}_{2} \mathrm{~S}$ (Jeroschewski et al., 1996), $\mathrm{N}_{2} \mathrm{O}$ (Andersen et al., 2001), and pH (Schulthess et al., 1981) were constructed at the Max Planck Institute for Marine Microbiology in Bremen (Germany) with a tip diameter of $\sim 10-30 \mu \mathrm{m}$ for $\mathrm{O}_{2}$, $\mathrm{H}_{2} \mathrm{~S}$ and $\mathrm{pH}$ and $\sim 150 \mu \mathrm{m}$ for $\mathrm{NO}_{3}^{-}$and $\mathrm{N}_{2} \mathrm{O}$. The sensors were calibrated each day and checked for proper functioning after profiling sulfidic sediments. Microsensor measurements were made in the 6 sediment cores that were connected to the incubation set up. In each core 3 to 12 profiles were measured at randomly selected spots. The custommade programmes $\mu$-Profiler, DAQ-server, and LINPOSserver were used for measurement automation and data acquisition (see http://www.microsen-wiki.net). Vertical profiles were recorded in steps of 250 or $500 \mu \mathrm{m}$, starting at $3 \mathrm{~mm}$ above the sediment surface and ending $10-20 \mathrm{~mm}$ below the sediment surface. 
To determine the vertical distribution of DEN activity in the sediment, the acetylene inhibition technique (Sørensen, 1978) was used in three cores that were incubated over night at $10 \%$ acetylene saturation in the overlying water. Acetylene inhibits the last step of denitrification so that $\mathrm{N}_{2} \mathrm{O}$ becomes the end product which accumulates in the sediment and can be measured with an $\mathrm{N}_{2} \mathrm{O}$ microsensor. Acetylene also inhibits anammox (Jensen et al., 2007), but this does not affect the denitrification-derived $\mathrm{N}_{2} \mathrm{O}$ production because anammox does not produce significant amounts of $\mathrm{N}_{2} \mathrm{O}$. Additionally, acetylene inhibits nitrification (Berg et al., 1982), but since $\mathrm{NO}_{3}^{-}$was supplied at a relatively high concentration via the water column, decreases in denitrification-derived $\mathrm{N}_{2} \mathrm{O}$ production due to inhibited nitrification activity were not to be expected. Thus, the acetylene inhibition technique as used here exclusively quantifies denitrification of $\mathrm{NO}_{3}^{-}$ supplied via the water column.

As a measure of DEN activity, the $\mathrm{N}_{2} \mathrm{O}$ flux $(J)$ between the layer of $\mathrm{N}_{2} \mathrm{O}$ production (which coincides with the layer of $\mathrm{NO}_{3}^{-}$consumption) and the sediment surface was calculated from the upper linear $\mathrm{N}_{2} \mathrm{O}$ concentration gradient using Fick's law of diffusion:

$J=-D_{\mathrm{s}} \cdot \Delta \mathrm{C} / \Delta \mathrm{x}$

with $D_{\mathrm{s}}$ as the sedimentary diffusion coefficient of $\mathrm{N}_{2} \mathrm{O}$ and $\Delta \mathrm{C} / \Delta \mathrm{x}$ as the linear $\mathrm{N}_{2} \mathrm{O}$ concentration gradient. $D_{\mathrm{s}}$ was calculated from the diffusion coefficient in water $\left(D_{w}\right)$ and the porosity $(\varphi)$ of the respective sediment as

$D_{\mathrm{s}}=D_{\mathrm{w}} \cdot \varphi /\left[1-\ln \left(\varphi^{2}\right)\right]$

(Boudreau, 1996). For $\mathrm{N}_{2} \mathrm{O}, D_{\mathrm{w}}$ was taken as $1.8 \times 10^{-5}$, $2.07 \times 10^{-5}$ and $2.4 \times 10^{-5} \mathrm{~cm}^{2} \mathrm{~s}^{-1}$ at 15,21 and $25^{\circ} \mathrm{C}$, respectively (Broecker and Peng, 1974). For $\mathrm{NO}_{3}^{-}, D_{\mathrm{w}}$ was taken as $1.5 \times 10^{-5}, 1.7 \times 10^{-5}$ and $1.9 \times 10^{-5} \mathrm{~cm}^{2} \mathrm{~s}^{-1}$ at 15,21 and $25^{\circ} \mathrm{C}$, respectively (Li and Gregory, 1974). $\varphi$ was determined as the loss of weight in 3 subcores sliced into $2 \mathrm{~mm}$ layers down to $20 \mathrm{~mm}$. Sediment slices of known volume were weighed and then dried at $65^{\circ} \mathrm{C}$ until weight constancy was achieved.

For the quantitative comparison with the $\mathrm{NO}_{3}^{-}$flux into the $\mathrm{NO}_{3}^{-}$-consuming layer, the upward $\mathrm{N}_{2} \mathrm{O}$ flux was multiplied by 2 to account for the downward $\mathrm{N}_{2} \mathrm{O}$ flux that could not be directly determined because the lower $\mathrm{N}_{2} \mathrm{O}$ concentration gradient was not in steady state. Since the overlying water was amended with $50 \mu \mathrm{mol} \mathrm{L}{ }^{-1} \mathrm{NO}_{3}^{-}$(which in most cases was higher than the in situ concentration on the day of sediment collection ranging from 2 to $124 \mu \mathrm{mol} \mathrm{L}^{-1}$ ), the $\mathrm{NO}_{3}^{-}$removal pathways in the sediment may have been stimulated. The obtained fluxes might thus be considered as potential fluxes.

Total dissolved sulfide (i.e., the sum of $\mathrm{H}_{2} \mathrm{~S}, \mathrm{HS}^{-}$, and $\mathrm{S}^{2-}$ ) was calculated from the $\mathrm{H}_{2} \mathrm{~S}$ and $\mathrm{pH}$ microprofiles according to Jeroschewski et al. (1996). The $p K_{1}$ value (i.e., the dissociation coefficient for the equilibrium between $\mathrm{H}_{2} \mathrm{~S}$ and $\mathrm{HS}^{-}$) was corrected for temperature and salinity of the respective sampling site according to Millero et al. (1988).

\subsection{Combined gel probe and isotopic labeling technique}

The depth distribution of DNRA activity was measured using the gel probe stable isotope technique of Stief et al. (2010) with minor modifications. Briefly, the pre-hydrated polyacrylamide gel in the probe, deoxygenated with $\mathrm{He}$, were inserted into the sediment. Forty-eight hours later, the overlying water was amended with ${ }^{15} \mathrm{~N}$-labelled $\mathrm{NO}_{3}^{-}\left(99 \%{ }^{15} \mathrm{~N}\right.$ atom $\%$, Cambridge Isotope Laboratories, Andover, MA, USA) to a final concentration of $50 \mu \mathrm{mol} \mathrm{L}-1$. The probes were left in the sediment for another $24-48 \mathrm{~h}$ for complete equilibration with the pore water. After retrieving the probes, the gel was immediately cut into a series of $201 \mathrm{~mm}$ pieces with a home-made cutter. Each slice was placed in a preweighed $3 \mathrm{~mL}$ vial (Exetainer; Labco, High Wycombe, UK), weighed again, and flushed twice with $\mathrm{He}$ for $60 \mathrm{~s}$ (with 1 min equilibration time in between) followed by the hypobromite assay described above. Samples from the Mississippi Delta and Janssand experiments were spiked with $50 \mu \mathrm{L}$ of $10 \mu \mathrm{mol} \mathrm{L}{ }^{-1}{ }^{14} \mathrm{NH}_{4}^{+}$. In headspace samples of $100-250 \mu \mathrm{L}$, the isotope ratio of ${ }^{28} \mathrm{~N}_{2},{ }^{29} \mathrm{~N}_{2}$, and ${ }^{30} \mathrm{~N}_{2}$ was determined by GC-IRMS (VG Optima, ISOTECH, Middlewich, UK) against air standards. Calibration standards were prepared with MilliQ water adjusted to different ${ }^{15} \mathrm{NH}_{4}^{+}$concentrations $\left(0,5,10\right.$, and $25 \mu \mathrm{mol} \mathrm{L}{ }^{-1} ;{ }^{15} \mathrm{NH}_{4} \mathrm{Cl} 98 \%{ }^{15} \mathrm{~N}$ atom $\%$, Cambridge Isotope Laboratories, Andover, MA, USA). Gel probes were immersed in the standard solutions and allowed to equilibrate for $24 \mathrm{~h}$. After incubation, the gel standards were treated in the same way as described above. For each ${ }^{15} \mathrm{NH}_{4}^{+}$concentration, 3-5 replicate gel slices were analysed. The ${ }^{15} \mathrm{NH}_{4}^{+}$concentration was calculated from the isotope ratios of ${ }^{28} \mathrm{~N}_{2},{ }^{29} \mathrm{~N}_{2}$, and ${ }^{30} \mathrm{~N}_{2}$ in the sample and in air standards using equations given by Risgaard-Petersen et al. (1995). Samples from the Mississippi Delta and the Janssand sediment were corrected for the added spike concentration. In addition, all profiles were corrected for the natural abundance of ${ }^{15} \mathrm{NH}_{4}^{+}$in the pore water of coastal marine sediment as found by Prokopenko et al. (2011) (i.e., 0.374 ${ }^{15} \mathrm{~N}$-Atom \%), which only had a minor influence on the calculated fluxes.

As a measure of DNRA activity, the ${ }^{15} \mathrm{NH}_{4}^{+}$flux between the layer of ${ }^{15} \mathrm{NH}_{4}^{+}$production (if coinciding with the layer of $\mathrm{NO}_{3}^{-}$consumption) and the sediment surface was calculated from the steady-state concentration profiles using Eqs. (1) and (2). The diffusion coefficient of $\mathrm{NH}_{4}^{+}\left(\mathrm{D}_{\mathrm{w}}\right)$ was taken as $1.5 \times 10^{-5}, 1.8 \times 10^{-5}$ and $2.0 \times 10^{-5} \mathrm{~cm}^{2} \mathrm{~s}^{-1}$ at 15,21 and $25^{\circ} \mathrm{C}$, respectively (Li and Gregory, 1974). For the quantitative comparison with the $\mathrm{NO}_{3}^{-}$flux into the $\mathrm{NO}_{3}^{-}$-consuming layer, the upward ${ }^{15} \mathrm{NH}_{4}^{+}$flux was multiplied by 2 to account for the downward ${ }^{15} \mathrm{NH}_{4}^{+}$flux that could not be directly determined because the lower ${ }^{15} \mathrm{NH}_{4}^{+}$concentration gradient 
was not in steady state. Also the ${ }^{15} \mathrm{NH}_{4}^{+}$fluxes may be considered as potential fluxes because of the relatively high $\mathrm{NO}_{3}^{-}$ concentrations in the overlying water.

Since only few ${ }^{15} \mathrm{NH}_{4}^{+}$concentration profiles featured curvatures that could be used for the above calculations, but clearly showed elevated ${ }^{15} \mathrm{NH}_{4}^{+}$concentrations, DNRA activity was also estimated as the depth-integrated rate of ${ }^{15} \mathrm{NH}_{4}^{+}$production. This rate was calculated as the sum of all ${ }^{15} \mathrm{NH}_{4}^{+}$concentration values of a profile multiplied by sediment porosity and the step size of the concentration profile and divided by the exposure time of the gel probe. Underlying assumptions were that the ${ }^{15} \mathrm{NH}_{4}^{+}$concentrations were zero at the start of the incubation (the natural abundance of ${ }^{15} \mathrm{NH}_{4}^{+}$is already accounted for in the ${ }^{15} \mathrm{NH}_{4}^{+}$concentration profiles) and increased linearly over time. The depthintegrated rate of ${ }^{15} \mathrm{NH}_{4}^{+}$production has the units of a flux, but is lower than the steady-state flux calculated above because it does not account for losses of ${ }^{15} \mathrm{NH}_{4}^{+}$due to adsorption, consumption, and diffusion during the exposure time of the gel probe.

\subsection{Porewater analyses}

For $\mathrm{NO}_{3}^{-}$and $\mathrm{NH}_{4}^{+}$analyses, 3 sediment sub cores (inner diameter of $2.6 \mathrm{~mm}$ ) were taken from each sampling site and cut into $2 \mathrm{~mm}$ slices down to a depth of $20 \mathrm{~mm}$. To each sediment slice $2 \mathrm{~mL}$ of artificial seawater (Red Sea Fish Farm, Israel) adjusted to the respective in situ salinity were added. After thorough mixing, the sediment suspension was centrifuged at $1000 \mathrm{~g}$ for $10 \mathrm{~min}$ and the supernatant was analysed for $\mathrm{NO}_{3}^{-}$and $\mathrm{NH}_{4}^{+}$as described above. The dilution with artificial seawater and the weight of the sediment slices were taken into account for the calculation of pore water concentrations.

For the determination of total dissolved iron after Viollier et al. (2000), 3 sub cores were cut into $2 \mathrm{~mm}$ slices down to $20 \mathrm{~mm}$. All plastic ware was cleaned with acid (suprapure $\mathrm{HNO}_{3}$ Merck, Darmstadt) and solutions were made with deoxygenated water. Cutting of sediment sub-cores and handling of the sediment slices were done in a $\mathrm{N}_{2}$-flushed glove box. The sediment slices were weighed and $1.5 \mathrm{~mL}$ of anoxic MilliQ $\mathrm{H}_{2} \mathrm{O}$ was added. The mixed samples were centrifuged ( $5 \mathrm{~min}$ at $3000 \mathrm{~g}$ ) and the supernatant was removed completely and filtered (Millipore, Millex-GN $13 \mathrm{~mm}$ ). The pelleted sediment was used for solid-phase iron analysis described below. For pore water analyses $1 \mathrm{~mL}$ of the filtered sample was taken (Viollier et al., 2000). Samples were measured undiluted, whereas the standards (prepared from a $1 \mathrm{mM}$ stock solution diluted with a $\mathrm{NaCl}$ solution at the salinity of the respective sampling site) were diluted $1: 2$ with 0.5 $\mathrm{M} \mathrm{HCl}$.

\subsection{Solid-phase sediment analysis}

\subsubsection{Sedimentary adsorption of ammonium}

The adsorption of DNRA-derived $\mathrm{NH}_{4}^{+}$to sediment was quantified in sediment sub cores cut into the layers 0-2, 27, and 7-12 mm. Sediment from the Mississippi Delta was cut into the layers $0-5$ and 5-10 mm only. Each slice was split into two pieces of approximately equal size. The sediment pieces were weighed and amended with $1.5 \mathrm{~mL}$ of one of the following anoxic solutions: (A) $\mathrm{NaCl}$ adjusted to the respective in situ salinity as a blank, (B) $\mathrm{NaCl}$ enriched with $50 \mu \mathrm{mol} \mathrm{L}-1{ }^{14} \mathrm{NH}_{4}^{+}$to mimic newly produced $\mathrm{NH}_{4}^{+}$. The sediment was incubated for $30 \mathrm{~min}$ and vigorously shaken every $10 \mathrm{~min}$. Following this incubation, the samples were centrifuged for $5 \mathrm{~min}$ at $3000 \mathrm{~g}$. In the supernatant, $\mathrm{NH}_{4}^{+}$was analysed as described above. The percentage of the added $\mathrm{NH}_{4}^{+}$that adsorbed to the sediment was calculated from the measured porewater $\mathrm{NH}_{4}^{+}$concentration (assay A) and the expected vs. the measured porewater $\mathrm{NH}_{4}^{+}$concentration after enrichment with $\mathrm{NH}_{4}^{+}$(assay B).

\subsubsection{Carbon-Nitrogen-Sulfur (CNS) content}

CNS was analysed in freeze-dried sediment aliquots by combustion gas chromatography (Carlo Erba NA-1500 CNS analyser).

\subsubsection{Acid-Volatile Sulfide (AVS) content}

Easily extractable sulfide (mainly FeS) was measured after Simpson (2001) in sediment sub cores cut for all sampling sites as described above for the iron determination. Samples were handled in a dinitrogen-flushed glove box and all the plastic ware was cleaned as described before. Solutions were made with deoxygenated water. The sediment slices were weighed and a subsample of $0.150-0.650 \mathrm{~g}$ wet weight was used for the subsequent analysis. Calibration standards were made in deoxygenated water out of a $100 \mathrm{mM} \mathrm{Na}_{2} \mathrm{~S}$ stock solution and diluted 1:10 with $1 \mathrm{M}$ suprapure $\mathrm{H}_{2} \mathrm{SO}_{4}$ (Merck, Darmstadt).

\subsubsection{Solid-phase iron content}

Extraction of solid-phase iron from the sediment was made with $0.5 \mathrm{M} \mathrm{HCl}$ for $1 \mathrm{~h}$ (Kostka and Luther, 1994). The extracts were filtered (Millipore, Millex-GN $13 \mathrm{~mm}$ ) and handled as described above for pore water iron analysis. The extracted sediment samples were diluted like the standard (see paragraph for pore water iron analyses) and measured after Viollier et al. (2000). 


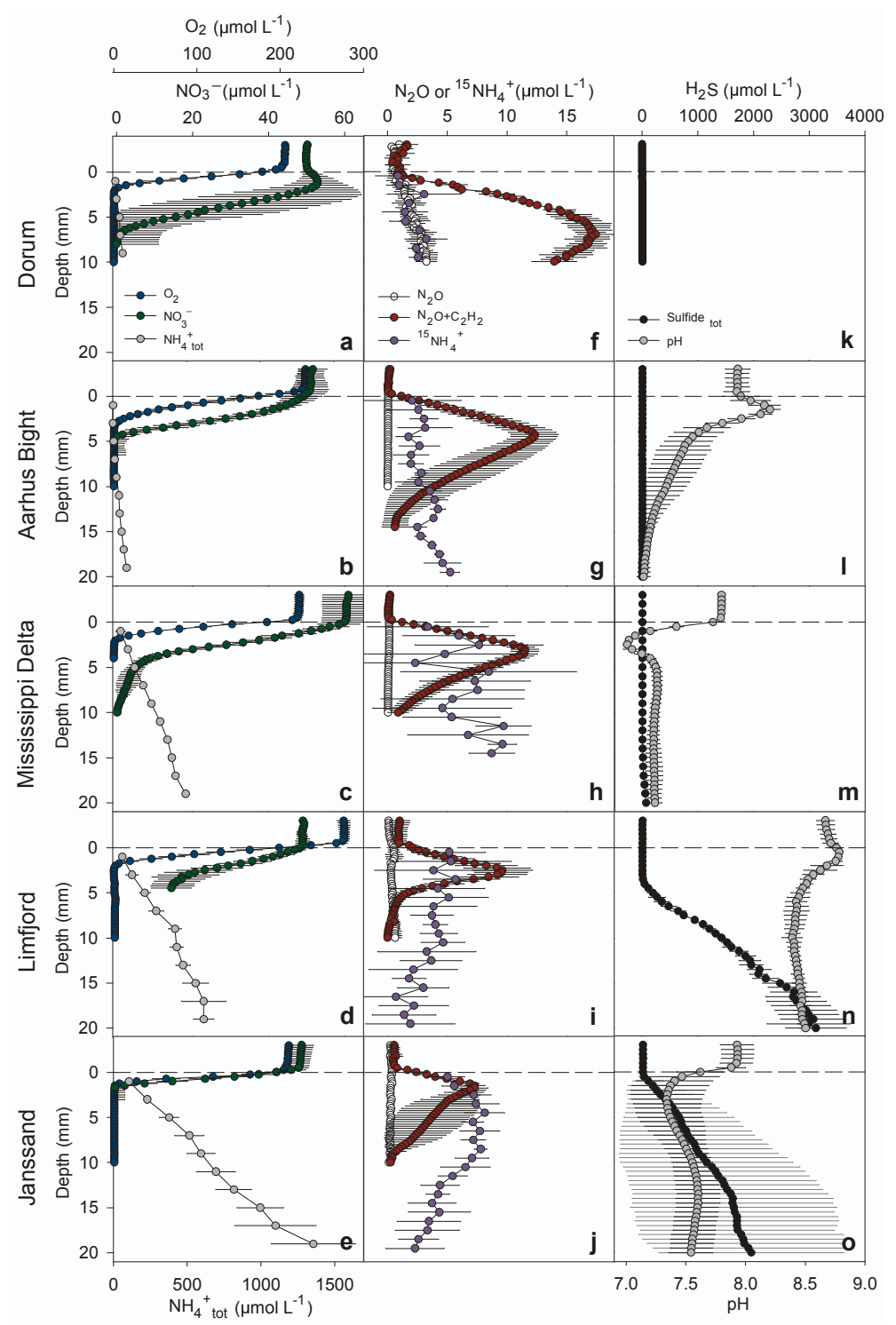

Fig. 1. Vertical profiles of $\mathrm{O}_{2}, \mathrm{NO}_{3}^{-}$and $\mathrm{NH}_{4}^{+}(\mathbf{a}-\mathbf{e}),{ }^{15} \mathrm{NH}_{4}^{+}$and $\mathrm{N}_{2} \mathrm{O}(\mathbf{f}-\mathbf{j})$ and $\mathrm{pH}$ and Sulfide tot $(\mathbf{k}-\mathbf{o})$ measured in intact sediment cores from different coastal marine sampling sites. The $\mathrm{NH}_{4}^{+}$profiles were measured in extracted pore water, ${ }^{15} \mathrm{NH}_{4}^{+}$profiles (indicating DNRA activity) were measured with gel probes, while the other profiles were measured with microsensors. The DEN activity profiles (represented by the $\mathrm{N}_{2} \mathrm{O}$ profiles with acetylene) were measured after inhibition of the last step of denitrification with acetylene. Means \pm standard deviation of 3-9 profiles are shown.

\section{Results}

\subsection{Characteristics of sampling sites and sediments}

The five sampling sites and sediments covered a wide range of environmental parameters and sediment characteristics (Tables 1 and 2). The five coastal marine sediments were muddy, sandy or muddy-to-sandy with porosities ranging from 45 to $85 \%$. At the time of sampling the sediments, $\mathrm{NO}_{3}^{-}$concentrations in the water column were generally low, with one notable exception at the freshwater-impacted Limfjord (124 $\mu \mathrm{mol} \mathrm{L}^{-1} \mathrm{NO}_{3}^{-}, 2 \%$ salinity). In situ temperatures ranged from 2.9 to $30.5^{\circ} \mathrm{C}$. Total carbon contents differed less than expected between the sediments and ranged from 0.6 to $3.0 \%$, while nitrogen contents were particularly low at Dorum $(0.02 \%)$ and highest at Aarhus Bight $(0.30 \%)$. The sediments differed largely in the capacity to adsorb $\mathrm{NH}_{4}^{+}$ produced by DNRA, with virtually no adsorption at Aarhus Bight and very high adsorption at Janssand (46\%).

\subsection{Vertical gradients of pore water concentrations}

Steady-state microprofiles of pore water solutes directly or indirectly involved in the activity of both DEN and DNRA 


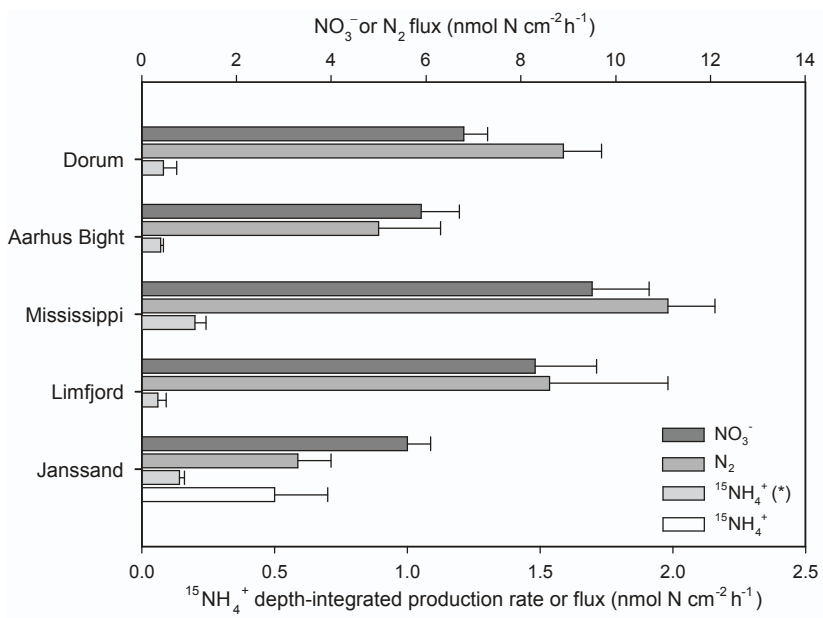

Fig. 2. Calculated $\mathrm{NO}_{3}^{-}$fluxes (from the sediment surface into the layer of $\mathrm{NO}_{3}^{-}$reduction) and $\mathrm{N}_{2}$ and ${ }^{15} \mathrm{NH}_{4}^{+}$fluxes (out of the layer of $\mathrm{N}_{2}$ and ${ }^{15} \mathrm{NH}_{4}^{+}$production) in intact sediment cores sampled at different coastal marine investigation sites. $\left(^{*}\right)$ Estimated from depth-integrated rates of ${ }^{15} \mathrm{NH}_{4}^{+}$production. Means + standard deviation of $n=4-12$ profiles are shown.

were measured in laboratory-incubated sediment cores from five coastal marine sampling sites (Fig. 1a-o).The penetration depth of $\mathrm{O}_{2}$ into the sediment was mostly around $2.5 \mathrm{~mm}$, except for the Janssand and Aarhus Bight sediments ( 1.5 and $3.5 \mathrm{~mm}$, respectively). $\mathrm{NO}_{3}^{-}$penetration always exceeded $\mathrm{O}_{2}$ penetration and was particularly deep in the Mississippi Delta sediment $(9 \mathrm{~mm})$. In the Dorum sediment, the $\mathrm{NO}_{3}^{-}$profiles revealed substantial nitrification activity at the surface, which increased $\mathrm{NO}_{3}^{-}$availability in the sediment. From the linear concentration gradient below the sediment surface, the $\mathrm{NO}_{3}^{-}$flux into the layer of dissimilatory nitrate reduction was calculated and was highest in the Mississippi Delta and lowest at Janssand (Fig. 2).

Ammonium concentrations generally increased with sediment depth. The concentration of $\mathrm{NH}_{4}^{+}$in the layer of $\mathrm{NO}_{3}^{-}$ reduction was high in Janssand, Limfjord and Mississippi Delta sediment (100 to $167 \mu \mathrm{mol} \mathrm{L}^{-1}$ ) and low in Dorum and Aarhus Bright ( 2 to $28 \mu \mathrm{mol} \mathrm{L}^{-1}$ ).

Total sulfide profiles derived from $\mathrm{H}_{2} \mathrm{~S}$ and $\mathrm{pH}$ microprofiles revealed substantial differences between the five sediments (Fig. 1k-o), with low concentrations in Dorum and the Aarhus Bight, intermediate concentrations in the Mississippi Delta and high concentrations in the Limfjord and Janssand sediments. In the Janssand sediment, heterogeneity was particularly high and at several spots total sulfide concentrations reached up to $3.9 \pm 1.7 \mathrm{mmol} \mathrm{L}^{-1}$.

\subsection{Vertical activity distribution of dissimilatory nitrate reduction}

Fluxes of $\mathrm{N}_{2}$ (measured as $\mathrm{N}_{2} \mathrm{O}$ upon acetylene inhibition) and ${ }^{15} \mathrm{NH}_{4}^{+}$were calculated from the concentration profiles shown in Fig. 1f $-\mathrm{j}$ and used as measures of DEN and DNRA activity, respectively. Beside these steady-state fluxes, the depth-integrated rate of ${ }^{15} \mathrm{NH}_{4}^{+}$production was calculated as an alternative estimate of DNRA activity (Fig. 2). In all sediments analysed here, DEN rather than DNRA was the dominant $\mathrm{NO}_{3}^{-}$respiration pathway. Only in the Janssand sediment, a significant ${ }^{15} \mathrm{NH}_{4}^{+}$flux directed from the layer of $\mathrm{NO}_{3}^{-}$consumption to the sediment surface could be measured.

After incubation with $10 \%$ acetylene, a distinct $\mathrm{N}_{2} \mathrm{O}$ concentration peak indicating DEN activity developed in the anoxic layer of the sediments from all sampling sites. The corresponding $\mathrm{N}_{2}$ fluxes were between $3.3 \pm 0.7$ and $11.1 \pm 1.0 \mathrm{nmol} \mathrm{N} \mathrm{cm}^{-2} \mathrm{~h}^{-1}$ (Fig. 2). Besides Dorum, in none of the sediments, $\mathrm{N}_{2} \mathrm{O}$ was detectable without acetylene inhibition (Fig. 1f-j).

A distinct concentration peak of ${ }^{15} \mathrm{NH}_{4}^{+}$ $(7.8 \pm 1.8 \mu \mathrm{mol} \mathrm{L}-1)$ in the layer of $\mathrm{NO}_{3}^{-}$reduction indicating DNRA activity was only detected in Janssand (Fig. 1j). The steady-state ${ }^{15} \mathrm{NH}_{4}^{+}$flux $\left(0.5 \pm 0.2 \mathrm{nmol} \mathrm{N} \mathrm{cm}^{-2}\right.$ $\mathrm{h}^{-1}$ ) was more than three times lower than the corresponding $\mathrm{N}_{2}$ flux. The calculated ${ }^{15} \mathrm{NH}_{4}^{+}$flux is possibly significantly underestimated since adsorption of $\mathrm{NH}_{4}^{+}$ to this sediment was particularly high (Table 2). Substantial ${ }^{15} \mathrm{NH}_{4}^{+}$concentrations were also found in other sediments (e.g., Mississippi Delta, $9.6 \pm 1.2 \mu \mathrm{mol} \mathrm{L}^{-1}$ ), indicating DNRA activity in these sediments. However, these scattered ${ }^{15} \mathrm{NH}_{4}^{+}$concentration profiles cannot be used for flux calculations like at Janssand because they do not feature a curvature indicative of steady-state ${ }^{15} \mathrm{NH}_{4}^{+}$ production. Instead, DNRA activity was estimated from the depth-integrated rate of ${ }^{15} \mathrm{NH}_{4}^{+}$production. In all sediments, including Janssand, ${ }^{15} \mathrm{NH}_{4}^{+}$production rates (ranging from $0.06 \pm 0.01$ to $0.16 \pm 0.08 \mathrm{nmol} \mathrm{N} \mathrm{cm}^{-2} \mathrm{~h}^{-1}$ ) were considerably lower than $\mathrm{NO}_{3}^{-}$consumption and $\mathrm{N}_{2}$ production rates. The highest ${ }^{15} \mathrm{NH}_{4}^{+}$production rates were found in sediment from Mississippi Delta and Janssand with $0.16 \pm 0.08 \mathrm{nmol} \mathrm{N} \mathrm{cm}^{-2} \mathrm{~h}^{-1}$ and $0.13 \pm 0.02 \mathrm{nmol} \mathrm{N} \mathrm{cm}^{-2} \mathrm{~h}^{-1}$, respectively (Fig. 2).

The relative partitioning between DEN and DNRA was assessed for each sampling site by a mass balance based on the $\mathrm{NO}_{3}^{-}, \mathrm{N}_{2},{ }^{15} \mathrm{NH}_{4}^{+}$fluxes and depth-integrated rates of ${ }^{15} \mathrm{NH}_{4}^{+}$production (Fig. 2, Table 3). At most sites, $\mathrm{NO}_{3}^{-}$ (the flux of which was set to $100 \%$ ) was quantitatively reduced to $\mathrm{N}_{2}$. In sediment from Dorum (130.6\%), the Mississippi Delta (116.9\%) and the Limfjord (103.2\%), even more $\mathrm{N}_{2}$ was produced than pore water $\mathrm{NO}_{3}^{-}$was consumed. In sediment from Janssand, however, only $59.0 \%$ of the $\mathrm{NO}_{3}^{-}$ consumed ended up as $\mathrm{N}_{2}$, while $8.9 \%$ (steady-state flux) 
Table 2. Sediment characteristics.

\begin{tabular}{lllll}
\hline Sampling site & Porosity $(\%)^{\mathrm{a}}$ & $\mathrm{C}(\mathrm{wt} \%)^{\mathrm{a}, \mathrm{b}}$ & $\mathrm{N}(\mathrm{wt} \%)^{\mathrm{a}, \mathrm{b}}$ & Adsorption of $\mathrm{NH}_{4}^{+}(\%)^{\mathrm{c}}$ \\
\hline Dorum & $45 \pm 6$ & $0.6 \pm 0.02$ & $0.02 \pm 0.00$ & $15 \pm 3.7$ \\
Aarhus Bight & $85 \pm 10$ & $3.5 \pm 0.37$ & $0.30 \pm 0.03$ & n.d. \\
Mississippi Delta & $81 \pm 9$ & $4.7 \pm 0.27$ & $0.31 \pm 0.03$ & $13 \pm 21.8$ \\
Limfjord & $62 \pm 13$ & $0.8 \pm 0.19$ & $0.09 \pm 0.02$ & n.d. \\
Janssand & $49 \pm 8$ & $0.8 \pm 0.30$ & $0.05 \pm 0.02$ & $46 \pm 1.5$ \\
\hline
\end{tabular}

${ }^{\mathrm{a}}$ Values for porosity, carbon and nitrogen contents are depth-integrated averages $(0-20 \mathrm{~mm}) .{ }^{\mathrm{b}}$ Carbon and nitrogen contents in the sediment are given in weight $\%$ of dry sediment. ${ }^{\mathrm{c}}$ Adsorption of $\mathrm{NH}_{4}^{+}$to sediment particles is given as percentage of $\mathrm{NH}_{4}^{+}$added to sediment slices from the depth of $\mathrm{NO}_{3}^{-}$reduction $(2-5 \mathrm{~mm})$. Means and standard deviations of 3 subsamples are shown. n.d.: not determined.

or $2.5 \%$ (depth-integrated production rate) was converted to $\mathrm{NH}_{4}^{+}$. Taking the $\mathrm{NH}_{4}^{+}$adsorption of $46 \%$ into account, the proportion of DNRA in $\mathrm{NO}_{3}^{-}$consumption might have been as high as $13.0 \%$ or $3.7 \%$, respectively, in this sediment. Although Mississippi Delta had the highest ${ }^{15} \mathrm{NH}_{4}^{+}$ concentrations and depth-integrated rate of ${ }^{15} \mathrm{NH}_{4}^{+}$production, Janssand was still the site with the highest relative share of DNRA activity in dissimilatory nitrate reduction (Table 3 ).

\subsection{Easily extractable solid-phase sulfide and iron}

Acid volatile sulfide (mainly FeS) showed for the Mississippi Delta, Limfjord and Janssand sediments a linear increase in concentration starting at the sediment surface (Fig. 3). In combination with the sulfide freely dissolved in the pore water, these three sampling sites had the highest amount of readily available sulfide species in the sediment.

Total dissolved iron had highest values in the Limfjord sediment, with a continuous increase from the sediment surface down to $20 \mathrm{~mm}$ (Fig. 3). A distinct peak was measured in Janssand starting at $3 \mathrm{~mm}$.

Solid phase iron showed no distinct distribution pattern at any of the sampling sites (Fig. 3), with concentrations ranging from $4.1 \pm 1.8$ to $12.6 \pm 3.2 \mu \mathrm{mol} \mathrm{g}^{-1}$ wet weight.

\subsection{Slurry experiment}

In addition to the whole core experiment, slurry incubations were conducted to test the differences in DEN and DNRA activities in a diffusive (whole core) vs. an advective setting (slurry).

In sediment from all three sampling sites (Dorum, Janssand upper tidal flat and low-water line near a sulfidic seep), the reduction of $\mathrm{NO}_{3}^{-}$was accompanied by the simultaneous production of ${ }^{15} \mathrm{~N}_{2}$ (DEN activity) and ${ }^{15} \mathrm{NH}_{4}^{+}$ (DNRA activity). In contrast to the whole core incubations, the relative share of DNRA in dissimilatory nitrate reduction was substantial in the slurry incubations of all three sediments (Fig. 4). 77, 56, and $37 \%$ of the observed $\mathrm{NO}_{3}^{-}$reduction in sediment from Janssand (low-water line), Janssand (upper flat), and Dorum, respectively, was explained by DNRA activity, while the remainder was explained by DEN activity (Fig. 4). The production of $\mathrm{N}_{2} \mathrm{O}$ was negligible in all slurred sediments (Fig. 4).

\section{Discussion}

\subsection{Relative importance of DEN and DNRA in coastal marine sediments}

\subsubsection{Whole core incubations}

In all coastal marine sediments studied as intact cores, denitrification (DEN) rather than DNRA was the dominant $\mathrm{NO}_{3}^{-}$ reduction pathway. DEN dominated irrespective of a large range of variation in sediment characteristics that are often discussed to favour either DEN or DNRA (e.g., sulfide concentration (An and Gardner, 2002; Brunet and GarciaGil, 1996), carbon-to-nitrate ratio (Tiedje et al., 1982; Yin et al., 2002)). In all but one sediment, $\mathrm{NO}_{3}^{-}$was quantitatively reduced to $\mathrm{N}_{2}$ within the bounds of accuracy of the methodical approach. In some cases, the $\mathrm{N}_{2}$ flux even exceeded the $\mathrm{NO}_{3}^{-}$ flux, which may have resulted from DEN activity by nitratestoring microorganisms.

In four out of five sediments, the vertical ${ }^{15} \mathrm{NH}_{4}^{+}$profiles measured with gel probes did not feature a distinct concentration peak in the layer of $\mathrm{NO}_{3}^{-}$reduction, which would be the strongest argument for DNRA activity. Since the $\mathrm{NH}_{4}^{+}$ adsorption capacity of these four sediments did not exceed $15 \%$, the majority of newly produced $\mathrm{NH}_{4}^{+}$would not have gone undetected by the gel probe technique. In fact, in all four sediments, the measured ${ }^{15} \mathrm{NH}_{4}^{+}$concentrations clearly exceeded the natural abundance of ${ }^{15} \mathrm{NH}_{4}^{+}$usually found in the pore water of coastal marine sediment (Prokopenko et al., 2011), indicating DNRA activity. However, due to the scatter, these ${ }^{15} \mathrm{NH}_{4}^{+}$concentration profiles could not be used for calculating steady-state ${ }^{15} \mathrm{NH}_{4}^{+}$fluxes. Instead, depthintegrated rates of ${ }^{15} \mathrm{NH}_{4}^{+}$production were calculated to estimate DNRA activity in these sediments. In all five sediments, low DNRA activities were detected using this calculation approach. Nevertheless, the scattered vertical distribution of ${ }^{15} \mathrm{NH}_{4}^{+}$that was observed in most sediments, suggests production mechanisms other than dissimilatory reduction 
Table 3. Mass balance for dissimilatory nitrate reduction in intact sediment cores sampled at five coastal marine investigation sites. Fluxes of $\mathrm{N}_{-} \mathrm{NO}_{3}^{-}$were set to $100 \%$ and fluxes of $\mathrm{N}-\mathrm{N}_{2}$ (indicating DEN activity) and ${ }^{15} \mathrm{~N}-\mathrm{NH}_{4}^{+}$(indicating DNRA activity) were calculated as relative shares of $\mathrm{NO}_{3}^{-}$fluxes. ${ }^{*}$ Estimated from depth-integrated rates of ${ }^{15} \mathrm{NH}_{4}^{+}$production; n.d.: not detected.

\begin{tabular}{lrrrr}
\hline Sampling site & $\mathrm{N}_{-} \mathrm{NO}_{3}^{-}(\%)$ & $\mathrm{N}^{-} \mathrm{N}_{2}(\%)$ & ${ }^{15} \mathrm{~N}^{-\mathrm{NH}_{4}^{+}(\%)}$ & ${ }^{15}{\mathrm{~N}-\mathrm{NH}_{4}^{+}}_{(\%)^{*}}$ \\
\hline Dorum & 100 & 130.6 & n.d. & 1.2 \\
Aarhus Bight & 100 & 84.6 & n.d. & 1.0 \\
Mississippi Delta & 100 & 116.9 & n.d. & 1.7 \\
Limfjord & 100 & 103.2 & n.d. & 0.8 \\
Janssand & 100 & 59.0 & 8.9 & 2.3 \\
\hline
\end{tabular}

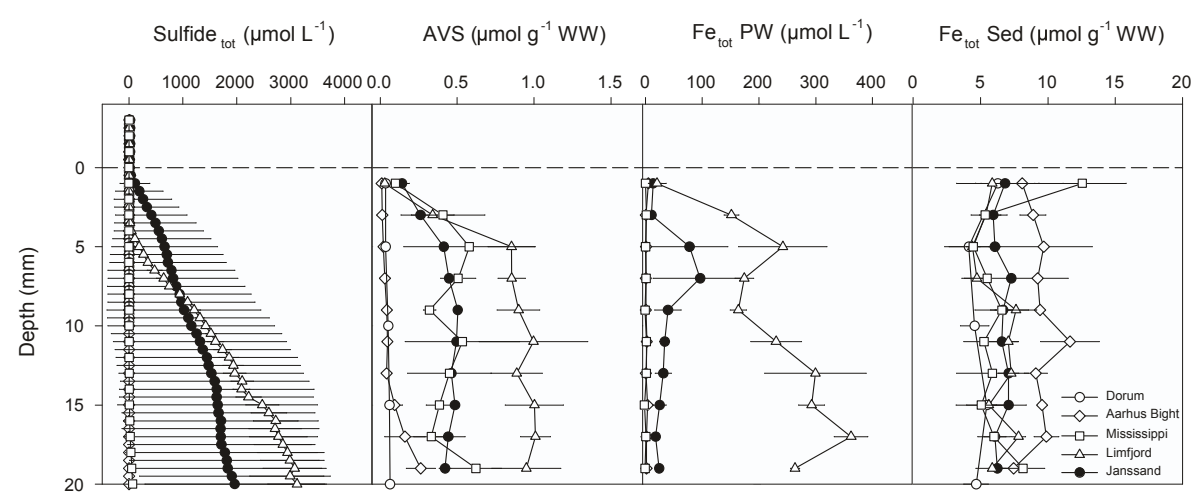

Fig. 3. Pore water sulfide (Sulfide $\left.\mathrm{tot}_{\mathrm{t}}\right)$, AVS (acid-volatile sulfide), Pore water iron $\left(\mathrm{Fe}_{\mathrm{tot}} \mathrm{PW}\right)$ and Solid-phase iron (Fe $\mathrm{ftot}_{\text {to }} \mathrm{Sed}$ ) of the different sampling sites. Solid-phase pools (AVS and solid-phase iron) are shown per gram wet weight (WW). Means \pm standard deviation of 3 replicate sub cores are shown.

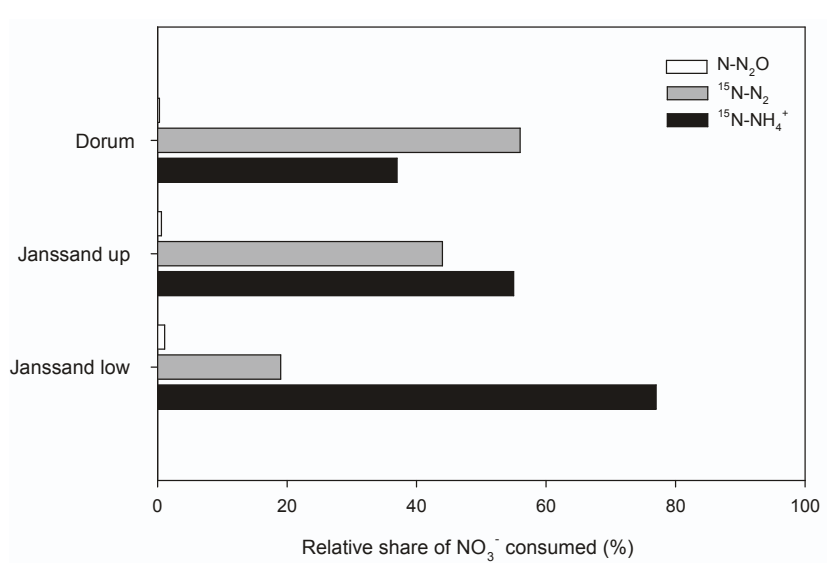

Fig. 4. Nitrogen mass balances of slurred sediments sampled at three coastal marine investigation sites calculated in relative shares of $\mathrm{N}_{-} \mathrm{NO}_{3}^{-}$consumption. $\mathrm{N}-\mathrm{NO}_{3}^{-}$consumption rates were set to $100 \%$ and production rates of ${ }^{15} \mathrm{~N}-\mathrm{N}_{2}$ (indicating DEN activity), ${ }^{15} \mathrm{~N}_{-} \mathrm{NH}_{4}^{+}$(indicating DNRA activity), and $\mathrm{N}-\mathrm{N}_{2} \mathrm{O}$ were calculated accordingly.

of porewater $\mathrm{NO}_{3}^{-}$such as intracellular nitrate storage and DNRA activity by migrating microorganisms (see below).

A notable exception to these observations was found in the sediment from Janssand (sampling site near sulfidic seeps).
In this case, the gel probe technique revealed a distinct concentration peak of ${ }^{15} \mathrm{NH}_{4}^{+}$that partially overlapped with the layer of $\mathrm{NO}_{3}^{-}$consumption. Based on the upper ${ }^{15} \mathrm{NH}_{4}^{+}$ concentration gradient, the ${ }^{15} \mathrm{NH}_{4}^{+}$flux out of the nitratereducing layer made up $8.9 \%$ of the $\mathrm{NO}_{3}^{-}$flux into the nitrate-reducing layer. Taking into account the high percentage of $\mathrm{NH}_{4}^{+}$adsorption in this sediment (46\%), the relative partitioning of dissimilatory nitrate reduction between DEN and DNRA might have been close to 82 and $18 \%$, respectively. These values are within the range found in other marine sediments, with DNRA activity accounting for 11-75\% and DEN accounting for 5-98\% of the total reduced $\mathrm{NO}_{3}^{-}$ (An and Gardner, 2002; Bonin et al., 1998; Dong et al., 2011; Koop-Jakobsen and Giblin, 2010; Porubsky et al., 2009).

The nitrogen budget in the Janssand sediment (and in Aarhus Bight sediment) was not closed; in these the $\mathrm{NO}_{3}^{-}$ flux exceeded the combined fluxes of $\mathrm{N}_{2}$ and ${ }^{15} \mathrm{NH}_{4}^{+}$. Possible explanations are assimilation of $\mathrm{NO}_{3}^{-}$by sediment microorganisms, anammox (not measured in this study) or intracellular storage of $\mathrm{NO}_{3}^{-}$by sulfide-oxidizing bacteria, foraminifera, and diatoms (Kamp et al., 2011; McHatton et al., 1996; Risgaard-Petersen et al., 2006; Sayama, 2001). The latter scenario, however, would only apply to non-steadystate conditions when nitrate-storing microorganisms with exhausted stores fill up their vacuoles. Additionally, the high 
sulfide concentrations in the sediment pore water may have alleviated the inhibition of $\mathrm{N}_{2} \mathrm{O}$ reduction by acetylene, which is known to underestimate DEN rates (Sørensen et al., 1987). The opposite phenomenon (i.e., the combined flux of $\mathrm{N}_{2}$ and ${ }^{15} \mathrm{NH}_{4}^{+}$exceeding the $\mathrm{NO}_{3}^{-}$flux) was observed in sediment from Dorum and the Mississippi Delta. Also in this case, the intracellular storage of $\mathrm{NO}_{3}^{-}$by vertically migrating sulfide-oxidizing bacteria, foraminifera, and diatoms may serve as a possible explanation (again only under nonsteady-state conditions). $\mathrm{NO}_{3}^{-}$taken up at the sediment surface and transported to deep layers will not be reflected in the steady-state pore water profile of $\mathrm{NO}_{3}^{-}$, whereas its dissimilatory reduction in deep layers will be reflected in the porewater profiles of $\mathrm{N}_{2}$ (measured as $\mathrm{N}_{2} \mathrm{O}$ ) and ${ }^{15} \mathrm{NH}_{4}^{+}$. In fact, intracellularly stored $\mathrm{NO}_{3}^{-}$was detected in Dorum sediment (up to $22.3 \mu \mathrm{mol} \mathrm{NO} \mathrm{Nm}^{-} \mathrm{dm}^{-3}$, Stief et al., 2013) where the discrepancy between $\mathrm{NO}_{3}^{-}$and $\mathrm{N}_{2}$ fluxes was particularly pronounced, but in Mississippi Delta sediment no stored $\mathrm{NO}_{3}^{-}$ could be detected.

The downward transport of ${ }^{15} \mathrm{NO}_{3}^{-}$by migrating cells may also be responsible for the shape of the ${ }^{15} \mathrm{NH}_{4}^{+}$concentration peak observed in Janssand sediment. A closer look at this peak reveals that it extends to well below the layer of $\mathrm{NO}_{3}^{-}$penetration. Non-steady-state modeling confirmed that the shape of this peak cannot be explained by downward diffusion and accumulation of ${ }^{15} \mathrm{NH}_{4}^{+}$at depth during the exposure time of the gel probe of 2 days (data not shown). Hence, a faster spreading of the ${ }^{15} \mathrm{NH}_{4}^{+}$concentration peak by moving cells seems more likely. Nitrate-storing and migrating microorganisms performing DNRA might be responsible for the deep occurrence of ${ }^{15} \mathrm{NH}_{4}^{+}$and for the scatter in the ${ }^{15} \mathrm{NH}_{4}^{+}$profiles measured in the other four sediments.

\subsubsection{Slurry incubations}

In all three sediments incubated as slurries, both DEN and DNRA contributed substantially to dissimilatory nitrate reduction. A direct comparison with whole core incubations is possible for the sediments from Dorum and Janssand (sampling site near sulfidic seeps) which have been used in both types of incubation. For Dorum sediment, the whole core incubation revealed DEN activity exclusively, while the slurry incubation revealed a relative partitioning between DEN and DNRA of 61 and $39 \%$, respectively of the total reduced $\mathrm{NO}_{3}^{-}$. For Janssand sediment, the slurry incubation shifted the partitioning from a dominance of DEN (i.e., 87 vs. $13 \%$ or 94 vs. $6 \%$ ) in the whole core incubation to a dominance of DNRA (i.e., 18 vs. $82 \%$ ). In sediment from the upper flat in Janssand and Dorum tested in slurries, the nitrogen budget was closed, leaving no room for a substantial involvement of intracellular $\mathrm{NO}_{3}^{-}$storage, microbial $\mathrm{NO}_{3}^{-}$assimilation, or $\mathrm{NH}_{4}^{+}$adsorption. At the low water line from Janssand $6 \%$ of the total nitrogen budget are missing that could account for the above mentioned additional $\mathrm{NO}_{3}^{-}$sinks. Additionally,
$\mathrm{N}_{2} \mathrm{O}$ production did not exceed $1 \%$ of the $\mathrm{NO}_{3}^{-}$consumption, but interestingly the highest $\mathrm{N}_{2} \mathrm{O}$ production rate was found in the most sulfidic sediment, probably due to partial inhibition of dissimilatory $\mathrm{N}_{2} \mathrm{O}$ reduction (Brunet and GarciaGil, 1996; Sørensen et al., 1980) by sulfide.

\subsubsection{Whole core vs. slurry incubations}

It could be assumed that the different results obtained by the two types of sediment incubation are explained by much higher $\mathrm{NO}_{3}^{-}$consumption rates in the slurry incubations due to the advective vs. diffusive substrate supply. However, higher $\mathrm{NO}_{3}^{-}$consumption rates measured in slurry incubations vs. whole core incubations were only detected for Dorum $\left(-69.7 \mathrm{nmol} \mathrm{N} \mathrm{cm}{ }^{-3} \mathrm{~h}^{-1}\right.$ and $-23.1 \pm 4.2 \mathrm{nmol} \mathrm{N}$ $\mathrm{cm}^{-3} \mathrm{~h}^{-1}$, respectively) but not for Janssand (-47.0 nmol N $\mathrm{cm}^{-3} \mathrm{~h}^{-1}$ and $-42.4 \pm 4.1 \mathrm{nmol} \mathrm{N} \mathrm{cm}{ }^{-3} \mathrm{~h}^{-1}$, respectively). Alternatively, it may be speculated that in sediment slurries many more DNRA bacteria are supplied with $\mathrm{NO}_{3}^{-}$than in intact sediment cores, especially in the absence of advective porewater transport. When $\mathrm{NO}_{3}^{-}$is exclusively supplied by diffusion, many microorganisms capable of DNRA might be cut off the $\mathrm{NO}_{3}^{-}$supply from above because they reside deeper in the sediment than microorganisms capable of DEN. DNRA microorganisms are active only in sediment layers that are completely anoxic and in which strongly reducing conditions prevail, often characterised by near absence of $\mathrm{NO}_{3}^{-}$and presence of sulfide (Tiedje et al., 1982). In contrast, DEN microorganisms can cope well with oxic-anoxic shifts (e.g., due to porewater irrigation by the tides or burrowing animals) and therefore are active closer to the oxicanoxic interface in the sediment (Brettar and Rheinheimer, 1991; Thamdrup and Dalsgaard, 2008; Tiedje et al., 1982). In fact, the gel probe technique previously revealed that the activity maximum of DNRA was located slightly deeper in stream sediment than the activity maximum of DEN (Stief et al., 2010). In stratified sediments, DEN microorganisms have thus the potential to out compete DNRA microorganisms for $\mathrm{NO}_{3}^{-}$. The slurry incubation of sediment disrupts these stratifications and exposes all microorganisms to homogeneous conditions with respect to substrates and products. DNRA microorganisms and rates, even if irrelevant in situ (Christensen et al., 2000; Laverman et al., 2006; Revsbech et al., 2006) might thus get more important in the slurry incubations because here they are not nitrate-limited any longer. Taken together, slurry incubations may overestimate DNRA rates due to enhanced $\mathrm{NO}_{3}^{-}$supply, whereas whole core incubations may underestimate DNRA rates due to diminished $\mathrm{NO}_{3}^{-}$supply, especially in the absence of advection.

\subsection{Environmental factors controlling the partitioning between DEN and DNRA}

The five sampling sites were chosen to cover a range of environmental factors that are proposed to promote or repress 
either DEN or DNRA. These factors (e.g., availability of $\mathrm{NO}_{3}^{-}$and electron donors such as organic carbon, sulfide, or reduced iron) are thought to influence the partitioning of dissimilatory nitrate reduction between DEN and DNRA. In the following, the contrasting results observed for sediment from Janssand (with a high DNRA activity, irrespective of method used for rate calculation) and the remaining sampling sites will be viewed in the light of these factors.

\subsubsection{Nitrate and carbon}

The ratio of electron acceptor (i.e., $\mathrm{NO}_{3}^{-}$) to electron donor (i.e., organic carbon) is the most frequently mentioned partitioning factor between DEN and DNRA (Fazzolari et al., 1998; Kelso et al., 1999; Tiedje, 1982, 1988; Yin et al., 2002). Supposedly, DNRA is the favoured pathway under nitratelimited conditions, while DEN is the favoured pathway under nitrate-replete conditions. Slightly more energy is gained per mol $\mathrm{NO}_{3}^{-}$by DNRA than by DEN (Strohm et al., 2007) and additionally DNRA consumes more electrons during the reduction of $\mathrm{NO}_{3}^{-}$to $\mathrm{NH}_{4}^{+}$. Low $\mathrm{NO}_{3}^{-}$and high organic carbon availability can thus create conditions favourable for DNRA rather than DEN (Christensen et al., 2000; Herbert, 1999; Megonigal et al., 2003; Nizzoli et al., 2006; Tiedje, 1988).

While the amended $\mathrm{NO}_{3}^{-}$availability in the overlying water of the whole core incubations was kept at the same level for all sediments, the total carbon and organic carbon contents varied considerably. Obviously though, high total carbon contents had no stimulating effect on DNRA because in the two sediments with the highest values (Mississippi Delta and Aarhus Bight), DNRA activity was only detected using the depth-integrated rate of ${ }^{15} \mathrm{NH}_{4}^{+}$production as a minimum estimate. On the contrary, substantial DNRA activity was detected in Janssand sediment with comparably low total carbon content.

At the time of sediment collection, in situ $\mathrm{NO}_{3}^{-}$concentrations in the water column were in most cases lower than the $50 \mu \mathrm{mol} \mathrm{L}{ }^{-1} \mathrm{NO}_{3}^{-}$used in the whole core incubations. The sudden increase in $\mathrm{NO}_{3}^{-}$supply to the sediments has certainly stimulated the $\mathrm{NO}_{3}^{-}$removal pathways, and in the worst case also shifted the in situ partitioning between DEN and DNRA in favour of DEN. However, over an annual cycle, most coastal marine sediments experience large fluctuations in water column $\mathrm{NO}_{3}^{-}$to which the microbial communities in the sediments are adapted. At Dorum, for instance, water column $\mathrm{NO}_{3}^{-}$varies between 2 and $80 \mu \mathrm{mol} \mathrm{L}{ }^{-1} \mathrm{NO}_{3}^{-}$(Stief et al., 2013), in Janssand mean values of $\sim 67 \mu \mathrm{mol} \mathrm{L}^{-1}$ were observed in the overlaying water (Gao et al., 2011) and in the Aarhus Bight, bottom water concentrations occasionally reach $25 \mu \mathrm{mol} \mathrm{L}{ }^{-1} \mathrm{NO}_{3}^{-}$(Lomstein et al., 1990). The $\mathrm{NO}_{3}^{-}$ amendments made in the whole core incubations, which were a methodical necessity for studying $\mathrm{NO}_{3}^{-}$removal pathways in the sediments, were hence within or not far off the range of in situ concentrations. It can thus be assumed that the exper- imentally determined partitioning between DEN and DNRA were also within the range of in situ partitioning values.

\subsubsection{Sulfide}

High sulfide concentrations in the sediment pore water have a strong influence on the activity of both DEN and DNRA (An and Gardner, 2002; Brunet and GarciaGil, 1996; Burgin and Hamilton, 2007; Christensen et al., 2003; Nizzoli et al., 2006). Sulfide can serve as an electron donor for DEN and DNRA, but at very high concentration it inhibits the last step of DEN, but not DNRA. Sulfidic sediments therefore tend to have a high capacity to reduce $\mathrm{NO}_{3}^{-}$and to produce $\mathrm{N}_{2} \mathrm{O}$ and $\mathrm{NH}_{4}^{+}$(An and Gardner, 2002; Brunet and GarciaGil, 1996).

An almost gradual increase in free total sulfide concentrations was observed in the sediments reaching from Aarhus Bight via Dorum, Mississippi, and Janssand, to Limfjord, but this increase was not reflected in increases of $\mathrm{NO}_{3}^{-}$consumption and $\mathrm{N}_{2} \mathrm{O}$ or ${ }^{15} \mathrm{NH}_{4}^{+}$production. The only striking findings were the substantial DNRA activity (irrespective of the method used for rate calculation) and the low DEN activity measured in Janssand sediment in which the second highest sulfide concentrations occurred. However, even in this sediment, DEN activity dominated dissimilatory nitrate reduction. Possibly, heterotrophic denitrifiers were out competed by autotrophic denitrifiers who can oxidize sulfide to sulfate in the presence of $\mathrm{NO}_{3}^{-}$and therefore exist even in sediments high in sulfide (Brinkhoff et al., 1998; Shao et al., 2009). The role of sulfide in stimulating DNRA can be further questioned based on the results of the slurry incubations. During the experimental procedure, the in situ concentration of freely dissolved sulfide was diluted approximately 3 -fold by the addition of sulfide-free seawater. Despite the diluted sulfide concentrations, clear shifts from DEN to DNRA were observed for the Dorum and Janssand sediments, contradicting the sulfide hypothesis. Finally, there was also no correlation between the sedimentary contents of acid-volatile sulfide and the occurrence of DNRA as there were even higher concentrations at Limfjord than at Janssand or Mississippi Delta. A peculiar feature of the Janssand sediment was the coincidence of very high sulfide and $\mathrm{NH}_{4}^{+}$concentrations. Even though the possible role of a high background concentration of $\mathrm{NH}_{4}^{+}$for DNRA activity remains unclear, it might still be used as an indicator of highly reduced sediment where DNRA is more likely to occur than in less reduced sediment.

\subsubsection{Iron}

Besides carbon and sulfide, reduced iron can serve as another electron donor for dissimilatory nitrate reduction. For Geobacter and Dechloromonas spp., it has been shown that iron is used to reduce $\mathrm{NO}_{3}^{-}$quantitatively to $\mathrm{NH}_{4}^{+}$(Weber et al., 2006a, c). In the present study, no distinct correlation between the appearance of iron (pore water and solid-phase) and DNRA or DEN activity in the sediments was observed. 
Nevertheless, in Janssand the sediment with the highest measurable DNRA activity in whole core incubations, porewater iron concentrations were the second highest in this study. The solid-phase iron contents were similar at all five sampling sites.

\subsubsection{Temperature}

Seasonally or habitat-specific high temperatures were shown to favour DNRA over DEN activity (Dong et al., 2011; Jørgensen, 1989; Ogilvie et al., 1997). In our study, in situ temperatures ranged from $\sim 3$ to $30^{\circ} \mathrm{C}$ and at the particularly warm sampling site in the Mississippi Delta, high DNRA activity was expected (Dong et al., 2011). Indeed, the ${ }^{15} \mathrm{NH}_{4}^{+}$pore water concentrations and the depth-integrated rates of ${ }^{15} \mathrm{NH}_{4}^{+}$production were the highest ones encountered in this study (Figs. 1 and 2). However, the variability of data from replicate gels was very pronounced and only the depth-integrated rates of ${ }^{15} \mathrm{NH}_{4}^{+}$production revealed DNRA activity in this sediment. The average ${ }^{15} \mathrm{NH}_{4}^{+}$profile as a whole can be questioned, however, because it also revealed high ${ }^{15} \mathrm{NH}_{4}^{+}$concentrations well below the $\mathrm{NO}_{3}^{-}$ penetration depth that are maybe explained by DNRA activity of nitrate-storing and migrating microorganisms. In addition, sediment from the Aarhus Bight and Dorum had similar depth-integrated rates of ${ }^{15} \mathrm{NH}_{4}^{+}$production, despite largely different incubation temperatures. We conclude that in our limited data set temperature was not a key factor that explained the presence or absence of DNRA activity.

\section{Conclusions}

This study investigated the relative share of two dissimilatory nitrate reduction pathways, DEN and DNRA, in coastal marine sediments. In none of the sediments studied here, DNRA was the dominant nitrate-reducing process. Nevertheless, the special conditions that prevail at Janssand apparently create a micro-environment in which DEN and DNRA can co-occur. At the low-water line, there is a high advective input of reduced compounds (e.g., sulfide and $\mathrm{NH}_{4}^{+}$) from the body of the tidal flat towards the sediment surface and a diffusive or advective input of $\mathrm{O}_{2}$ and $\mathrm{NO}_{3}^{-}$from the water column into the sediment (Billerbeck et al., 2006; Jansen et al., 2009; Røy et al., 2008). It can be assumed that microorganisms capable of DNRA cope better or benefit from the millimolar-range sulfide concentrations compared to DEN microorganisms. So unlike in non-sulfidic sediments, the in situ conditions at Janssand may have allowed DNRA microorganisms to thrive particularly well due to their sulfide tolerance and the lack of competition for $\mathrm{NO}_{3}^{-}$with DEN microorganisms. However, the whole core incubation turned the Janssand sediment into a non-seep sediment without advective inputs of sulfide from below and $\mathrm{O}_{2}$ and $\mathrm{NO}_{3}^{-}$from above. Thus, the whole core incubation presumably underestimates the relative share of
DNRA in dissimilatory nitrate reduction. On the contrary, the slurry incubation of Janssand sediment may overestimate the relative share of DNRA because of unlimited $\mathrm{NO}_{3}^{-}$supply to DNRA bacteria that are out competed for $\mathrm{NO}_{3}^{-}$by DEN bacteria in stratified sediments. The true partitioning of dissimilatory nitrate reduction between DNRA and DEN may consequently lie in between the values found in whole core and slurry incubations. It can be argued that the gel probe technique gives more realistic estimates of DNRA activity in diffusion-dominated sediments, while slurry incubations are more suitable for advection-dominated sediments. Further methodical improvements should aim at DNRA activity measurements in intact sediments with realistic advective dynamics, since DNRA is apparently important in coastal marine sediments in which advection creates microsites at which both $\mathrm{NO}_{3}^{-}$and sulfide are available.

Acknowledgements. We are grateful to the technicians of the Microsensor Group of the Max Planck Institute for Marine Microbiology (Bremen, Germany) for microsensor construction and the technicians of the Biogeochemistry Group for their practical assistance. We thank T. Vang and L. Flensborg, the crew of the research vessel Tyra (Aarhus University, Denmark), I. Heisterkamp, and A. Kolker (University Louisiana, USA) for help during sediment sampling. Moritz Holtappels and Gaute Lavik are thanked for fruitful discussions. This research was supported by the Max Planck Society and the German Research Foundation (STI202/4).

The service charges for this open access publication have been covered by the Max Planck Society.

Edited by: F. Meysman

\section{References}

An, S. M. and Gardner, W. S.: Dissimilatory nitrate reduction to ammonium (DNRA) as a nitrogen link, versus denitrification as a sink in a shallow estuary (Laguna Madre/Baffin Bay, Texas), Mar. Ecol. Prog.-Ser., 237, 41-50, 2002.

Andersen, K., Kjaer, T., and Revsbech, N. P.: An oxygen insensitive microsensor for nitrous oxide, Sens. Actuator B-Chem., 81, 4248, 2001.

Berg, P., Klemedtsson, L., and Rosswall, T.: Inhibitory effect of low partial pressures of acetylene on nitrification, Soil Biol. Biochem., 14, 301-303, doi:10.1016/0038-0717(82)900414, 1982.

Billerbeck, M., Werner, U., Polerecky, L., Walpersdorf, E., deBeer, D., and Huettel, M.: Surficial and deep pore water circulation governs spatial and temporal scales of nutrient recycling in intertidal sand flat sediment, Mar. Ecol. Prog.-Ser., 326, 61-76, 2006.

Bonin, P., Omnes, P., and Chalamet, A.: Simultaneous occurrence of denitrification and nitrate ammonification in sediments of the French Mediterranean Coast, Hydrobiologia, 389, 169-182, 1998.

Boudreau, B. P.: The diffusive tortuosity of fine-grained unlithified sediments, Geochim. Cosmochim. Ac, 60, 3139-3142, 1996. 
Bower, C. E. and Holm-Hansen, T.: A salicylate-hypochlorite method for determining ammonium in seawater, Can. J. Fish. Aquat. Sci., 37, 794-798, 1980.

Braman, R. S. and Hendrix, S. A.: Nanogram nitrite and nitrate determination in environmental and biological materials by vanadium(III) reduction with chemiluminescence detection, Anal. Chem., 61, 2715-2718, 1989.

Brettar, I. and Rheinheimer, G.: Denitrification in the Central Baltic: evidence for $\mathrm{H}_{2} \mathrm{~S}$-oxidation as motor of denitrification at the oxic-anoxic interface, Mar. Ecol. Prog.-Ser., 77, 157-169, 1991.

Brinkhoff, T., Santegoeds, C. M., Sahm, K., Kuever, J., and Muyzer, G.: A polyphasic approach to study the diversity and vertical distribution of sulfur-oxidizing Thiomicrospira species in coastal sediments of the German Wadden Sea, Applied Environ. Microb., 64, 4650-4657, 1998.

Broecker, W. S. and Peng, T. H.: Gas exchange rates between air and sea, Tellus, 26, 21-35, 1974.

Brunet, R. C. and GarciaGil, L. J.: Sulfide-induced dissimilatory nitrate reduction to ammonia in anaerobic freshwater sediments, FEMS Microbiol. Ecol., 21, 131-138, 1996.

Burgin, A. J. and Hamilton, S. K.: Have we overemphasized the role of denitrification in aquatic ecosystems? A review of nitrate removal pathways, Front. Ecol. Environ., 5, 89-96, 2007.

Christensen, P. B., Rysgaard, S., Sloth, N. P., Dalsgaard, T., and Schwaerter, S.: Sediment mineralization, nutrient fluxes, denitrification and dissimilatory nitrate reduction to ammonium in an estuarine fjord with sea cage trout farms, Aquat. Microb. Ecol., 21, 73-84, 2000.

Christensen, P. B., Glud, R. N., Dalsgaard, T., and Gillespie, P.: Impacts of longline mussel farming on oxygen and nitrogen dynamics and biological communities of coastal sediments, Aquaculture, 218, 567-588, 2003.

Dalsgaard, T., Thamdrup, B., and Canfield, D. E.: Anaerobic ammonium oxidation (anammox) in the marine environment, Rese. Microbiol., 156, 457-464, doi:10.1016/j.resmic.2005.01.011, 2005.

Dong, L. F., Smith, C. J., Papaspyrou, S., Stott, A., Osborn, A. M., and Nedwell, D. B.: Changes in Benthic Denitrification, Nitrate Ammonification, and Anammox Process Rates and Nitrate and Nitrite Reductase Gene Abundances along an Estuarine Nutrient Gradient (the Colne Estuary, United Kingdom), Appl. Environ. Microb., 75, 3171-3179, 2009.

Dong, L. F., Sobey, M. N., Smith, C. J., Rusmana, I., Phillips, W., Stott, A., Osborn, A. M., and Nedwell, D. B.: Dissimilatory reduction of nitrate to ammonium, not denitrification or anammox, dominates benthic nitrate reduction in tropical estuaries, Limnol. Oceanogr., 56, 279-291, 2011.

Dunn, R. J. K., Welsh, D. T., Jordan, M. A., Waltham, N. J., Lemckert, C. J., and Teasdale, P. R.: Benthic metabolism and nitrogen dynamics in a sub-tropical coastal lagoon: Microphytobenthos stimulate nitrification and nitrate reduction through photosynthetic oxygen evolution, Estuar. Coast. Shelf S., 113, 272-282, 2012.

Edwards, L., Kuesel, K., Drake, H., and Kostka, J. E.: Electron flow in acidic subsurface sediments co-contaminated with nitrate and uranium, Geochim. Cosmochim. Ac., 71, 643-654, 2007.

Fazzolari, E., Nicolardot, B., and Germon, J. C.: Simultaneous effects of increasing levels of glucose and oxygen partial pressures on denitrification and dissimilatory nitrate reduction to ammonium in repacked soil cores, Eur. J. Soil Biol., 34, 47-52, 1998.
Fernandes, S. O., Bonin, P. C., Michotey, V. D., Garcia, N., and LokaBharathi, P. A.: Nitrogen-limited mangrove ecosystems conserve $\mathrm{N}$ through dissimilatory nitrate reduction to ammonium, Sci. Rep., 2, 1-5, doi:10.1038/srep00419 2012.

Gao, H., Schreiber, F., Collins, G., Jensen, M. M., Svitlica, O., Kostka, J. E., Lavik, G., de Beer, D., Zhou, H.-Y., and Kuypers, M. M. M.: Aerobic denitrification in permeable Wadden Sea sediments (vol 4, p. 417, 2010), Isme J., 5, 776-776, doi:10.1038/ismej.2010.166, 2011.

Gardner, W. S. and McCarthy, M. J.: Nitrogen dynamics at the sediment-water interface in shallow, sub-tropical Florida Bay: why denitrification efficiency may decrease with increased eutrophication, Biogeochem., 95, 185-198, 2009.

Gardner, W. S., McCarthy, M. J., An, S., Sobolev, D., Sell, K. S., and Brock, D.: Nitrogen fixation and dissimilatory nitrate reduction to ammonium (DNRA) support nitrogen dynamics in Texas estuaries, Limnol. Oceanogr., 51, 558-568, 2006.

Gilbert, F., Souchu, P., Bianchi, M., and Bonin, P.: Influence of shellfish farming activities on nitrification, nitrate reduction to ammonium and denitrification at the water-sediment interface of the Thau lagoon, France, Mar. Ecol. Prog.-Ser., 151, 143-153, 1997.

Herbert, R. A.: Nitrogen cycling in coastal marine ecosystems, Fems Microbiol. Rev., 23, 563-590, 1999.

Jansen, S., Walpersdorf, E., Werner, U., Billerbeck, M., Bottcher, M. E., and de Beer, D.: Functioning of intertidal flats inferred from temporal and spatial dynamics of $\mathrm{O}_{2}, \mathrm{H}_{2} \mathrm{~S}$ and $\mathrm{pH}$ in their surface sediment, Ocean Dynam., 59, 317-332, 2009.

Jensen, M. M., Thamdrup, B., and Dalsgaard, T.: Effects of specific inhibitors on anammox and denitrification in marine sediments, Appl. Environ. Microb., 73, 3151-3158, doi:10.1128/aem.01898-06, 2007.

Jeroschewski, P., Steuckart, C., and Kuhl, M.: An amperometric microsensor for the determination of $\mathrm{H}_{2} \mathrm{~S}$ in aquatic environments, Anal. Chem., 68, 4351-4357, 1996.

Jørgensen, K. S.: Annual pattern of denitrification and nitrate ammonification in estuarine sediment, Appl. Environ. Microb., 55, 1841-1847, 1989.

Kamp, A., de Beer, D., Nitsch, J. L., Lavik, G., and Stief, P.: Diatoms respire nitrate to survive dark and anoxic conditions, Proc. Natl. Acad. Sci. USA, 108, 5649-5654, 2011.

Kelly-Gerreyn, B. A., Trimmer, M., and Hydes, D. J.: A diagenetic model discriminating denitrification and dissimilatory nitrate reduction to ammonium in a temperate estuarine sediment, Mar. Ecol. Prog.-Ser., 220, 33-46, 2001.

Kelso, B. H. L., Smith, R. V., and Laughlin, R. J.: Effects of carbon substrates on nitrite accumulation in freshwater sediments, Appl. Environ. Microb., 65, 61-66, 1999.

King, D. and Nedwell, D. B.: The influence of nitrate concentration upon the end-products of nitrate dissimilation by bacteria in anaerobic salt marsh sediment, FEMS Microbiol. Ecol., 31, 23 28,1985

Koop-Jakobsen, K. and Giblin, A. E.: The effect of increased nitrate loading on nitrate reduction via denitrification and DNRA in salt marsh sediments, Limnol.Oceanogr., 55, 789-802, 2010.

Kostka, J. E. and Luther, G. W.: Partitioning and speciation of solid phase iron in saltmarsh sediments, Geochim. Cosmochim. Ac., 58, 1701-1710, 1994. 
Lansdown, K., Trimmer, M., Heppell, C. M., Sgouridis, F., Ullah, S., Heathwaite, A. L., Binley, A., and Zhang, H.: Characterisation of the key pathways of dissimilatory nitrate reduction and their response to complex organic substrates in hyporheic sediments, Limnol. Oceanogr., 57, 387-400, 2012.

Larsen, L. H., Kjaer, T., and Revsbech, N. P.: A microscale $\mathrm{NO}_{3}^{-}$biosensor for environmental applications, Anal. Chem., 69, 3527-3531, 1997.

Laverman, A. M., Van Cappellen, P., van Rotterdam-Los, D., Pallud, C., and Abell, J.: Potential rates and pathways of microbial nitrate reduction in coastal sediments, FEMS Microbiol. Ecol., 58, 179-192, 2006.

Li, Y. H. and Gregory, S.: Diffusion of ions in sea water and in deepsea sediments, Geochim. Cosmochim. Ac., 38, 703-714, 1974.

Lomstein, E., Jensen, M. H., and Sorensen, J.: Benthic $\mathrm{NH}_{4}^{+}$and $\mathrm{NO}_{3}^{-}$flux following sedimentation of a spring phytoplankton bloom in Aarhus Bight, Denmark, Mar. Ecol. Prog.-Ser., 61, 97105, doi:10.3354/meps061097, 1990.

Lovley, D. R., Holmes, D. E., and Nevin, K. P.: Dissimilatory $\mathrm{Fe}(\mathrm{III})$ and $\mathrm{Mn}(\mathrm{IV})$ reduction, Adv. Microb. Physiol., 49, 219286, 2004.

McHatton, S. C., Barry, J. P., Jannasch, H. W., and Nelson, D. C.: High nitrate concentrations in vacuolate, autotrophic marine Beggiatoa spp, Appl. Environ. Microb., 62, 954-958, 1996.

Megonigal, J. P., Hines, M. E., and Visscher, P. T.: Anaerobic metabolism: linkages to trace gases and aerobic processes, edited by: Schlesinger, W. H., Biogeochemistry, vol 8, Biogeochemistry, Elsevier, Oxford, 2003.

Millero, F. J., Plese, T., and Fernandez, M.: The dissociation of hydrogen sulfide in seawater, Limnol. Oceanogr., 33, 269-274, 1988.

Nizzoli, D., Welsh, D. T., Fano, E. A., and Viaroli, P.: Impact of clam and mussel farming on benthic metabolism and nitrogen cycling, with emphasis on nitrate reduction pathways, Mar. Ecol. Prog.-Ser., 315, 151-165, 2006.

Ogilvie, B. G., Rutter, M., and Nedwell, D. B.: Selection by temperature of nitrate-reducing bacteria from estuarine sediments: Species composition and competition for nitrate, FEMS Microbiol. Ecol., 23, 11-22, 1997.

Porubsky, W. P., Weston, N. B., and Joye, S. B.: Benthic metabolism and the fate of dissolved inorganic nitrogen in intertidal sediments, Estuar. Coast. Shelf S., 83, 392-402, 2009.

Prokopenko, M. G., Sigman, D. M., Berelson, W. M., Hammond, D. E., Barnett, B., Chong, L., and Townsend-Small, A.: Denitrification in anoxic sediments supported by biological nitrate transport, Geochim. Cosmochim. Ac., 75, 7180-7199, 2011.

Revsbech, N. P.: An oxygen microsensor with a guard cathode, Limnol. Oceanogr., 34, 474-478, 1989.

Revsbech, N. P., Risgaard-Petersen, N., Schramm, A., and Nielsen, L. P.: Nitrogen transformations in stratified aquatic microbial ecosystems, Antonie Van Leeuwenhoek International Journal of General and Molecular Microbiology, 90, 361-375, 2006.

Risgaard-Petersen, N., Rysgaard, S., and Revsbech, N. P.: Combined microdiffusion-hypobromite oxidation method for determining nitrogen-15 isotope in ammonium, Soil Sci. Soc. Am. J., 59, 1077-1080, 1995.

Risgaard-Petersen, N., Langezaal, A. M., Ingvardsen, S., Schmid, M. C., Jetten, M. S. M., Op den Camp, H. J. M., Derksen, J. W. M., Pina-Ochoa, E., Eriksson, S. P., Nielsen, L. P., Revsbech, N.
P., Cedhagen, T., and van der Zwaan, G. J.: Evidence for complete denitrification in a benthic foraminifer, Nature, 443, 93-96, 2006.

Røy, H., Lee, J. S., Jansen, S., and de Beer, D.: Tide-driven deep pore-water flow in intertidal sand flats, Limnol. Oceanogr., 53, 1521-1530, 2008.

Sayama, M.: Presence of nitrate-accumulating sulfur bacteria and their influence on nitrogen cycling in a shallow coastal marine sediment, Appl. Environ. Microb., 67, 3481-3487, 2001.

Schulthess, P., Shijo, Y., Pham, H. V., Pretsch, E., Ammann, D., and Simon, W.: A hydrogen ion-selective liquid-membrane electrode based on tri- $n$-dodecylamine as neutral carrier, Anal. Chim. Acta, 131, 111-116, 1981.

Seitzinger, S. P.: Denitrification in freshwater and coastal marine ecosystems: ecological and geochemical significance, Limnol. Oceanogr., 33, 702-724, 1988.

Shao, M., Zhang, T., and Fang, H. H. P.: Autotrophic denitrification and its effect on metal speciation during marine sediment remediation, Water Res., 43, 2961-2968, 2009.

Simpson, S. L.: A rapid screening method for acid-volatile sulfide in sediments, Environ. Toxicol. Chem., 20, 2657-2661, 2001.

Smyth, A. R., Thompson, S. P., Siporin, K. N., Gardner, W. S., McCarthy, M. J., and Piehler, M. F.: Assessing nitrogen dynamics throughout the estuarine landscape, Estuar. Coast., 36, 44-55, 2013.

Sørensen, J.: Denitrification rates in a marine sediment as measured by the acetylene inhibition technique, Appl. Environ. Microb., 36, 139-143, 1978.

Sørensen, J., Tiedje, J. M., and Firestone, R. B.: Inhibition by sulfide of nitric and nitrous oxide reduction by denitrifying Pseudomonas fluorescen, Appl. Environ. Microb., 39, 105-108, 1980.

Sørensen, J., Rasmussen, L. K., and Koike, I.: Micromolar sulfide concentrations alleviate acetylene blockage of nitrous oxide reduction by denitrifying Pseudomonas fluorescens, Can. J. Microbiol., 33, 1001-1005, 1987.

Stief, P., Behrendt, A., Lavik, G., and De Beer, D.: Combined gel probe and isotope labeling technique for measuring dissimilatory nitrate reduction to ammonium in sediments at millimeter-level resolution, Appl. Environ. Microb., 76, 6239-6247, 2010.

Stief, P., Kamp, A., and De Beer, D.: Role of diatoms in the spatialtemporal distribution of intracellular nitrate in intertidal sediment, Plos ONE, 8, e73257, doi:10.1371/journal.pone.0073257, 2013.

Strohm, T. O., Griffin, B., Zumft, W. G., and Schink, B.: Growth yields in bacterial denitrification and nitrate ammonification, Appl. Environ. Microb., 73, 1420-1424, 2007.

Thamdrup, B.: New Pathways and Pprocesses in the global nitrogen cycle, Annu. Rev. Ecol. Evol. S., 43, 407-428, 2012.

Thamdrup, B. and Dalsgaard, T.: Nitrogen cycling in sediments, in: Microbial ecology of the oceans, edited by: Kirchman, D. L., 2nd ed, John Wiley and Sons, 527-568, 2008.

Tiedje, J. M., Sexstone, A. J., Myrold, D. D., and Robinson, J. A.: Denitrification: ecological niches, competition and survival, Antonie Van Leeuwenhoek Journal of Microbiology, 48, 569-583, 1982.

Tiedje, J. M.: Ecology of denitrification and dissimilatory nitrate reduction to ammonium, in: Biology of anaerobicmicroorganisms, edited by: Zehnder, A. J. B., John Wiley and Sons, 179-244, 1988. 
Viollier, E., Inglett, P. W., Hunter, K., Roychoudhury, A. N., and Van Cappellen, P.: The ferrozine method revisited: $\mathrm{Fe}(\mathrm{II}) / \mathrm{Fe}(\mathrm{III})$ determination in natural waters, Appl. Geochem., 15, 785-790, 2000.

Warembourg, F. R.: Nitrogen fixation in soil and plant systems, in: In R. Knowles and T. H. Blackburn (ed.), Nitrogen isotope techniques, Academic Press, New York, 157-180, 1993.

Weber, K. A., Achenbach, L. A., and Coates, J. D.: Microorganisms pumping iron: anaerobic microbial iron oxidation and reduction, Nat. Rev. Microbiol., 4, 752-764, 2006a.

Weber, K. A., Pollock, J., Cole, K. A., O'Connor, S. M., Achenbach, L. A., and Coates, J. D.: Anaerobic nitrate-dependent iron(II) bio-oxidation by a novel lithoautotrophic betaproteobacterium, strain 2002, Appl. Environ. Microb., 72, 686-694, 2006b.
Weber, K. A., Urrutia, M. M., Churchill, P. F., Kukkadapu, R. K., and Roden, E. E.: Anaerobic redox cycling of iron by freshwater sediment microorganisms, Environ. Microb., 8, 100-113, $2006 \mathrm{c}$.

Yin, S. X., Chen, D., Chen, L. M., and Edis, R.: Dissimilatory nitrate reduction to ammonium and responsible microorganisms in two Chinese and Australian paddy soils, Soil Biol. Biochem., 34, 1131-1137, 2002. 